\title{
Expression of bcl-2 oncoprotein in pituitary tumours: comparison with c-myc
}

\author{
D-G Wang, C F Johnston, A B Atkinson, A P Heaney, M Mirakhur, K D Buchanan
}

\begin{abstract}
Aims/background-Whereas the control of hormone secretion from pituitary adenomas has been studied in considerable detail, the molecular events underlying the development of these tumours are still poorly understood. Abnormalities of some oncogenes and tumour suppressor genes have been previously reported to occur at very low frequencies. The aim of the present study was to assess the possible expression of the bcl-2 oncoprotein and to compare it with that of c-myc in pituitary adenomas.
\end{abstract}

Methods-Monoclonal antibodies were used, along with microwave antigen retrieval and the avidin-biotin immunohistochemical method, to investigate expression of the oncoproteins bcl-2 and c-myc in 30 primary pituitary tumours from five broad diagnostic groups and in five normal pituitaries.

Results-Bcl-2 and c-myc immunoreactivities were detected in nine $(30 \%)$ and eight $(27 \%)$ tumour samples, respectively. Of the nine bcl-2 and eight c-myc positive tumours, seven were positive for both oncoproteins and included one of the four corticotrophinomas studied, four of seven prolactinomas, one of two somatotrophinomas, and one of four oncocytomas. All 13 null cell adenomas studied were negative for both bcl-2 and c-myc immunoreactivities.

Conclusions-These results indicate that the bcl-2 and c-myc oncoproteins are expressed abnormally in over one quarter of pituitary tumours. Most these tumours co-expressed both oncoproteins. The genetic complementation of simultaneously deregulated bcl-2 and c-myc is implicated, through the regulation of apoptosis, in the pathogenesis of pituitary tumours. (f Clin Pathol 1996;49:795-797)

Keywords: bcl-2, pituitary tumour, apoptosis.

Sir George E Clark

Victoria Hospital,

Belfast

A B Atkinson

A P Heaney

Correspondence to: Dr Da-Gong Wang, c/o Dr Colin F Johnston, Wellcome Research Laboratories, Institute of Clinical Science, Grosvenor Road Belfast BT12 6BJ. and to invade adjacent structures. Despite recent advances in the diagnosis, localisation and treatment of these tumours, their exact ontogeny and carcinogenesis remain unknown.

Several genetic aberrations have been implicated in initiation of tumorigenicity, including
Pituitary tumours are monoclonal in origin, ${ }^{12}$ suggesting that they arise as clonal expansions adenomas are benign neoplasms they have the activation of cellular protooncogenes or loss of function of tumour suppressor genes. ${ }^{3}$ It is generally accepted that these alterations typically result in enhanced rates of cellular proliferation. Recent evidence suggests that the genetic regulation of apoptosis is also of critical importance during tumorigenesis and that oncogene and tumour suppressor genes can regulate the rate, or susceptibility, of cells to undergo apoptosis. ${ }^{4} 5$ The participation of oncogenes and tumour suppressor genes in the regulation of apoptotic cell death during multistep carcinogenesis has recently become an area of intense investigation. ${ }^{45}$

The protein product of the $b c l-2$ oncogene is an inner mitochondrial membrane protein that blocks programmed cell death, ${ }^{6}$ thus giving the cells that overexpress this protein a survival advantage over normal cells. Deregulated c-myc expression plays a pivotal role in oncogenesis in a variety of experimental and naturally occurring tumours. Despite the apparent importance of c-myc in the induction of cell proliferation, expression of c-myc has recently been linked to the induction of cell death in different cells and cell lines, ${ }^{78}$ suggesting that this may be a general function of this protein. In this study we have investigated the expression of the bcl-2 and c-myc oncoproteins, by immunohistochemistry, using commercially prepared monoclonal antibodies, in 30 primary pituitary tumours from five broad diagnostic groups identified by clinical assessment and immunohistochemical demonstration of hormone content.

\section{Methods}

Consecutive pituitary tumours $(n=30)$, collected between 1992 and 1994, were reviewed retrospectively from the archives of the Department of Neuropathology, Royal Victoria Hospital, Belfast. The mean (range) age of the patients was $53(20-78)$ years and sex ratio was 1:1.3 (M:F). Tumour classifications are shown in table 1. Patients were diagnosed by standard clinical, biochemical and imaging criteria and the tumour identity was confirmed in each case by the diagnostic pathology service of the Royal Victoria Hospital by histological methods, electron microscopy and immunohistochemical staining for adrenocorticotropin $(\mathrm{ACTH})$, growth hormone $(\mathrm{GH})$, prolactin (PRL), follicle stimulating hormone (FSH), luteinising hormone (LH), and thyroid stimulating hormone (TSH). Tumour tissue had been fixed in formalin and embedded in paraffin wax according to a constant protocol. Five 
Table 1 Immunoreactivity of bcl-2 and c-myc oncoproteins in pituitary tumours

\begin{tabular}{lclll}
\hline Tumour type & $\begin{array}{l}\text { Number of } \\
\text { patients }\end{array}$ & Sex (M:F) & $\begin{array}{l}\text { Number positive for } \\
\text { bcl-2 }\end{array}$ & $\begin{array}{l}\text { Number positive for } \\
\text {-myc }\end{array}$ \\
\hline Corticotrophinoma & 4 & $3: 1$ & 2 & 1 \\
Prolactinoma & 7 & $1: 6$ & 4 & 5 \\
Somatotrophinoma & 2 & $1: 1$ & 2 & 1 \\
Oncocytoma & 4 & $3: 1$ & 1 & 1 \\
Null cell tumour & 13 & $7: 6$ & 0 & 0 \\
Normal pituitary & 5 & $1: 4$ & 0 & 0 \\
\hline
\end{tabular}

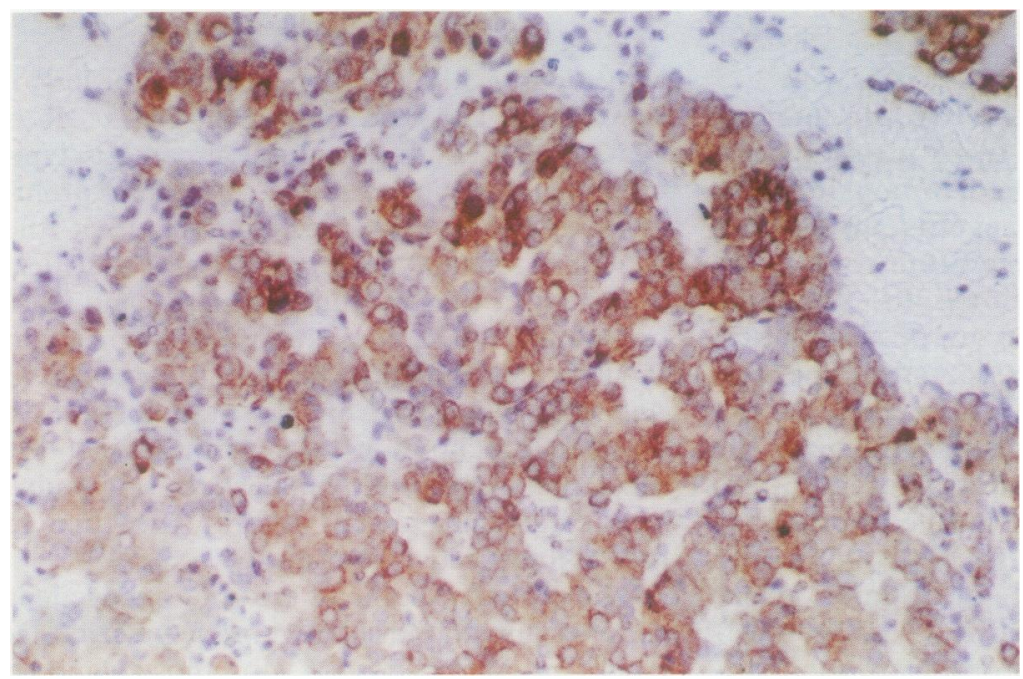

Figure 1 Intense cytoplasmic bcl-2 immunoreactivity in a pituitary prolactinoma. Streptavidin-biotin peroxidase reaction with light haematoxylin counterstaining.

normal pituitary glands obtained at necropsy were processed in a similar manner.

\section{IMMUNOHISTOCHEMISTRY}

Oncoprotein expression was detected using commercially prepared monoclonal antibodies specific for each protein. Immunohistochemical studies were performed by the avidin-biotin method. Briefly, $4 \mu \mathrm{m}$ paraffin wax sections were dewaxed and subjected to microwave antigen retrieval immersed in citrate buffer (pH 6.0) as described previously. ${ }^{9}$ Endogenous peroxidase was blocked with 3\% hydrogen peroxide for 15 minutes and sections were then treated with $20 \%$ normal rabbit serum for 20 minutes. Oncoprotein immunoreactivity was studied by incubation with primary antibodies directed against bcl-2 (diluted 1 in 50) (clone 124, Dako, Glostrup, Denmark), c-myc (diluted 1 in 100) (clone 9E11, Novocastra, Newcastle upon Tyne, UK) for one hour at room temperature, according to the manufacturer's instructions. Sections were then washed and incubated with a biotinylated secondary anti-

Table 2 Comparison of bcl-2 and c-myc oncoprotein immunoreactivities

\begin{tabular}{lll}
\hline Tumour type & $b c l-2$ & $c-m y c$ \\
\hline Corticotrophinoma & ++ & ++ \\
Prolactinoma & + & - \\
& +++ & +++ \\
& +++ & ++ \\
& + & +++ \\
Somatotrophinoma & ++ & +++ \\
Oncocytoma & +++ & +++ \\
& ++ & +
\end{tabular}

Semiquantitative score: - , negative; + , less than $10 \%$ of tumour cells positive;,$++ 10-50 \%$ of tumour cells positive; and +++ greater than $50 \%$ of tumour cells positive. body (Dako). After 35 minutes' incubation in avidin-biotin complex (Dako), the reaction product was visualised by 3,3-diaminobenzidine tetrahydrochloride (DAB) (Sigma, Poole, Dorset, UK). Finally, the sections were counterstained with haematoxylin.

Controls used throughout the staining procedure included staining of tissues that were either known positives or negatives for each oncoprotein, as well as incubation and development of sections using only normal blocking serum without incubation in primary antibody. The immunocytochemical results were assessed without knowledge of the pathological $\stackrel{\mathbb{\Omega}}{\Omega}$ and clinical diagnosis. Tumours were scored क semiquantitatively according to the number of $\vec{\circ}$ positive cells: - , negative; + , less than $10 \%$ of tumour cells positive;,$++ 10-50 \%$ of tumour $\vec{\omega}$ cells positive; and +++ , greater than $50 \%$ of $\frac{?}{0}$ tumour cells positive.

\section{Results}

IMMUNOREACTIVITY OF ONCOPROTEIN BCL-2 AND है C-MYC

All five normal pituitary tissues were negative for both bcl-2 and c-myc.

The bcl-2 and c-myc immunoreactivities in the different pituitary tumour groups are summarised in table 1 ; table 2 gives details of the semiquantitative scores for the individual positive cases.

Bcl-2 immunoreactivity was present in nine (30\%) tumours, including two corticotrophinomas, four prolactinomas, two somatotrophi- $\overline{0}$ nomas, and one oncocytoma. The percentage of tumour cells displaying positivity was $\mathbb{Q}$ variable (table 2 ) as was the intensity of the $\overrightarrow{\overrightarrow{0}}$ reaction, which ranged from weak to strong. Immunostaining was cytoplasmic and confined to the neoplastic cells (fig 1). Immunoreactivity for c-myc was observed in eight (27\%) 용 tumour samples, including one corticotrophinoma, five prolactinomas, one somatotrophinoma, and one oncocytoma. The indi- $\delta$ vidual tumour cells showed a diffuse $₹$ cytoplasmic staining pattern and the intensity 을 of staining varied from case to case, but was $D$ generally moderate.

\section{COMPARISON OF IMMUNOREACTIVITY OF BCL-2} AND C-MYC

All positive cases for bcl-2 or c-myc, or both, 0 are shown in table 2 . Of the nine bcl-2 positive and eight c-myc positive tumours, seven were $\frac{C}{\mathbb{C}}$ positive for both oncoproteins and included $\stackrel{\mathscr{P}}{+}$ one corticotrophinoma, four prolactinomas, $\overparen{T}$ one somatotrophinoma, and one oncocytoma.

All 13 null cell adenomas examined were negative for both bcl-2 and c-myc immunore- $\stackrel{\mathbb{Q}}{2}$ activity. There is, therefore, an association between the expression of the bcl-2 and c-myc oncoproteins in pituitary tumours.

\section{Discussion}

Pituitary tumours may be hormonally functional or non-secreting. Whereas the control of hormone secretion from these adenomas has been studied in considerable detail, the molecular events underlying the development of 
these tumours are still poorly understood. Mutations of the $g s p$ oncogene have been reported to occur in $40 \%$ of somatotroph adenomas. ${ }^{111} \mathrm{c}$-myc also has been reported to be overexpressed in a subgroup of pituitary tumours. ${ }^{12}$ Retinoblastoma, ras and p53 gene abnormalities as well as other genetic lesions have been reported to occur at very low frequencies. ${ }^{14-17}$ The present study reports, for the first time, expression of the bcl-2 oncoprotein in human pituitary tumours. Immunoreactivity for bcl-2 occurred in $30 \%$ of tumours and displayed a wide range of immunostaining intensities. As this investigation examined only paraffin wax embedded material, in which the immunoreactivity of many proteins is compromised, the true incidence of bcl- 2 expression in pituitary tumours may be higher than reported here.

Previous studies have demonstrated that the deregulation of programmed cell death is a critical component in multistep tumorigenesis. ${ }^{45}$ Several candidate genes, including $b c l-2$ and $c-m y c$ have been implicated in the regulation of programmed cell death. ${ }^{6}{ }^{18} \mathrm{De}-$ regulation of these genes has also been implicated as important events during the development of malignant tumours. ${ }^{19}{ }^{20}$ In the present study bcl-2 and c-myc immunoreactivity was found in nine and eight of 30 pituitary tumours, respectively. As seven cases were positive for both oncoproteins it is suggested that there is an association of expression between bcl-2 and c-myc.

The expression of bcl-2 in some pituitary tumours suggests that it may be involved in their pathogenesis. Korsmeyer ${ }^{21}$ suggested that alterations of a gene such as $b c l-2$, which controls cell death, could be a frequent primary aberration in follicular lymphoma along with other types of neoplasms. The observation of bcl-2 expression in some pituitary tumours, which are slow growing, suggests that in these tumours, bcl-2 expression may represent an initial event leading to indolent tumour growth. It is known that bcl-2 promotes cell survival even when the rate of cell proliferation is low, thereby providing a growth advantage that may eventually lead to neoplastic transformation. ${ }^{22}$

Recently, it has been demonstrated that constitutive c-myc expression can result in the induction of apoptotic cell death in cell lines under growth limiting conditions. ${ }^{1823}$ However, c-myc induced apoptotic cell death is inhibited by bcl-2, while cell proliferation enhanced by deregulated and overexpressed c-myc is not reduced. ${ }^{2425}$ While studies of the possible co-localisation of bcl-2 and c-myc in individual cells were beyond the scope of the present investigation, a notable association was observed between the presence of bcl-2 and c-myc immunoreactivities between tumours. This co-expression of bcl-2 and c-myc could indicate that bcl-2, by mitigating the apoptotic effects of deregulated c-myc expression without affecting its ability to promote continuous cell growth, provides a mechanistic basis for the oncogenic synergy between these two protooncogenes in pituitary tumours.

In conclusion, the abnormal expression of oncoprotein bcl-2 in some pituitary tumours may contribute to their carcinogenesis. The genetic complementation of simultaneously deregulated bcl-2 and c-myc may be implicated in the multistep tumorigenesis of pituitary tumours.

We wish to thank Mrs Kathy M Pogue for her expert technical assistance.

This work was supported by grants from the Ulster Cancer Foundation and the Clinical Research Awards Advisory Committee of the Department of Health and Social Services, Northern Ireland.

1 Herman V, Fagin J, Gonsky R, Kovacs K, Melmed S. Clonal origin of pituitary adenomas. $\mathcal{f}$ Clin Endocrinol Metab 1990;71:1427-33.

2 Alexander JM, Biller BMK, Bikkal H, Zervas NT, Arnold A, Klibanski A. Clinically nonfunctioning pituitary tumours are monoclonal in origin. $₹$ Clin Invest $1990 ; 86: 336-40$.

3 Bishop MJ. Molecular genetics of cancer. Science 1987;235: 305-11.

4 Williams GT, Smith CA. Molecular regulation of apoptosis: genetic controls on cell death. Cell 1993;74:777-9.

5 McDonnell TJ. Cell division versus dell death: a functional model of multistep neoplasia. Mol Carcinog 1993;8:209-13.

6 Hockenbery D, Nunez G, Milliman C, Schreiber RD, Korsmeyer SJ. Bcl-2 is an inner mitochondrial membrane protein that blocks programmed cell death. Nature 1990;348:334-6.

7 Evan GI, Wyllie AH, Gilbert CS, Littlewood TD, Land $\mathrm{H}$, Brooks $M$, et al. Induction of apoptosis in fibroblasts by c-myc protein. Cell 1992;69:119-28.

8 Askew D, Ashmun R, Simmons B, Cleveland J. Constitutive c-myc expression in IL-3 dependent myeloid cell line suppresses cycle arrest and accelerates apoptosis. Oncogene 1991;6:1915-22.

9 Wang DG, Johnston CF, Anderson N, Sloan JM, Buchanan $\mathrm{KD}$. Overexpression of the tumour suppressor gene $\mathrm{p} 53$ is not implicated in neuroendocrine tumour carcinogenesis. $\mathcal{F}$ Pathol 1995; 175:397-401.

10 Landis CA, Masters SB, Spada A, Pace AM, Bourne HR, Vallar L. GTPase inhibiting mutations activate the chain of GS and stimulate adenyl cyclase in human pituitary GS and stimulate adenyl cyclase

11 Vallar L, Spada A, Giannattasio G. Altered GS and adenylate cyclase activity in human GH-secreting pituitary tumours. Nature 1987;330:566-8.

12 Woloschak M, Roberts JL, Post K. c-myc, c-fos, and c-myb gene expression in human pituitary tumours. 7 Clin Endocrinol Metabol 1994;79:253-7.

13 Raghavan R, Harrison D, Ince PG, Janes RA, Daniels M, Birch $\mathrm{P}$, et al. Oncoprotein immunoreactivity in human pituitary tumours. Clin Endocrinol 1994;40:117-26

14 Karga HJ, Alexander JM, Hedley-Whyte ET, Klibanski A Jameson JL. Ras mutations in human pituitary tumours. $\mathscr{f}$ Clin Endocrinol Metab 1992;74:914-9.

15 Herman V, Drazin NZ, Gonsky R, Melmed S. Molecular screening of pituitary adenomas for gene mutations and rearrangements. F Clin Endocrinol Metab 1993;77:50-5.

16 Cryns VL, Alexander JM, Klibanski A, Arnold A. The retinoblastoma gene in human pituitary tumours. $f$ Clin Endocrinol Metab 1993;77:644-6.

17 Woloschak M, Roberts JL, Post K. Frequency of loss of heterozygosity at the retinoblastoma locus in human pituitary tumours. Cancer 1994;74:693-6.

18 Shi Y, Glynn JM, Guilbert LJ, Cotter TG, Bissonnette RP, Green DR. Role for c-Myc in activation-induced apoptotic cell death in T cell hybridomas. Science 1992;257:212-14.

19 McDonnell TJ, Korsmeyer. Progression from lymphoid hyperplasia to high-grade malignant lymphoma in mice transgenic for the $\mathrm{t}(14 ; 18)$. Nature 1991;349:254-6.

20 Schmidt EV, Pattengale PK, Weir L, Leder P. Transgenic mice bearing the human c-Myc gene activated by an immunoglobulin enhancer; a pre-B-cell lymphoma model. Proc Natl Acad Sci USA 1988;85:6047-51.

21 Korsmeyer SJ. Bcl-2 initiates a new category of oncogenes: Korsmeyer SJ. Bcl-2 initiates a new category of

22 Vaux DL, Cory S, Adama JM. bcl-2 gene promotes haemopoietic cell survival and cooperaties with c-myc to immortalize pre B cells. Nature 1988;335:440-2.

23 Evan GI, Wyllie AH, Gilbert CS, Littlewood TD, Land H, Brooks $M$, et al. Induction of apoptosis in fibroblasts by c-myc protein. Cell 1992;69:119-28.

24 Fanidi A, Harrington EA, Evan GI. Cooperative interaction between c-myc and bcl-2 proto-oncogenes. Nature 1992; 359:554-6.

25 Wagner AJ, Small MB, Hay N. Myc-mediated apoptosis is blocked by ectopic expression of Bcl-2. Mol Cell Biol 1993; 13:2432-40. 